\title{
PERFORMANCE MANAGEMENT \\ IN PROTECTED AREAS: LOCALIZING \\ GOVERNANCE OF THE CURONIAN \\ SPIT NATIONAL PARK, LITHUANIA
}

\author{
Valentina Burksiene \\ Associate Professor of Department of Public Administration and Political \\ Sciences, Faculty of Social Sciences and Humanities, Klaipeda University. \\ Address: H. Manto 84, 92294 Klaipeda, Lithuania. \\ E-mail:v.burksiene@gmail.com
}

\section{Jaroslav Dvorak}

Associate Professor Head of Department of Public Administration and Political

Sciences, Faculty of Social Sciences and Humanities, Klaipeda University.

Address: H. Manto 84, 92294 Klaipeda, Lithuania.

E-mail: Jaroslav.dvorak@ku.lt

\begin{abstract}
Bottom-up performance management, which is common in the countries with an old democracy, seems to be a challenge in Lithuania (a country with a young democracy) due to its strictly hierarchical governing and planning system. The situation of a national park on the Curonian Spit, which is also a UNESCO protected area, is most complicated in regards to performance management and governance. Problems related to developing (from one side) and protection (from the other) led to discussions among the state and local politicians, administrators and stakeholders on the possibility of steering the area with a special law. The approach of comparative analysis of similar territories worldwide revealed that the unique context of each protected area requires individual solutions, but not the application of special laws. However, managing the performance of the Curonian Spit seems to be a challenge for local actors. The approach of qualitative interviews was used with local officials and experts in order to reveal the main aspects and expectations/critics of performance management and governance. Findings provided that the success of performance management in protected areas of countries of young democracy largely depends on the network flattening and real involvement of locals and indigenous people in public governance.
\end{abstract}

Keywords: Performance management; performance measurement; protected areas; national park; governance; local community; indigenous people; UNESCO.

Citation: Burksiene, V. \& Dvorak, J. (2020). Performance Management in Protected Areas: Localizing Governance of the Curonian Spit National Park, Lithuania. Public Administration Issues, no 5, (Special Issue I, electronic edition), pp. 105-124 (in English); DOI: 10.17323/1999-5431-2020-0-5-105-124 


\section{Introduction}

Performance management is defined as transforming information from performance measurement, analysis, evaluation and benchmarking into knowledge and applying that knowledge for organizational improvement and learning. According to Lin and Lee (2011): No measurement - no performance, no performance - no management. Apparently, performance management is inseparable from performance measurement, which requires effective evaluation. Through performance management, governments gain knowledge of what is effective for society, why it is effective or not, and what are the outputs of interventions. In fact, performance management helps to make better decisions and, at the same time, contributes to the consolidation of organizational processes through the specific approach of performance measurement, which promotes stakeholder's engagement, guarantees transparency and supports the well-being of society. Conversely, performance measurement, due to certain conditions and to a certain extent, is less applied for its good governance mission than for cynical political purposes or not at all.

Performance management research and studies can be divided into four categories: (i) research papers that address the definitions and functions of performance management ${ }^{1}$; (ii) research papers on performance management models ${ }^{2}$; (iii) research that analyses the use of performance management in decision-making ${ }^{3}$; (iv) research on the institutionalization of performance management in new democracies 4 . Our study corresponds to the last category.

In the new democracies, research on performance management, measurement and utilization is only in its infancy. There is not much scientific work explaining the patterns common to these countries (Jong, 2015). These were not scientists but the officials of the supreme audit institutions of these countries who started to remedy the situation (Nõmm, Randma-Liiv, 2012). Existing research is mostly limited to one country, but there are also more extensive studies covering a few new democracies from EU countries (Verheijen, Dobrolyubova, 2007; Dvorak, 2010; Bouckaert, Nakrošis, Nemec, 2011; Kaselis, 2013; Veselý, 2013; Sorin, 2015; Rauleckas, Nakrošis, et al. 2016).

Protected areas play a significant role in sustainable development both globally and locally. Different sources (Watson, Allan, et.al. 2018; World Bank, 2019) calculate that up to 15 percent of the Globe is nature reserves. Many issues and challenges occur in the administration of such areas as they may be managed by several governing bodies (ministries and administrative jurisdictions) at any one time. Thus, Gerrish (2016) argues the importance of studying performance management from a cross pollinated perspective. The politicians and administrators

\footnotetext{
1 Boland, Fowler, (2000), Bouckaert, Halligan, (2007), Fryer, Antony, et al. (2009), Van Dooren, et al. (2010), Micheli, Mari, (2014), Cepiku, (2017).

2 Boland, Fowler, (2000), Verbeeten, (2008), Fryer, Antony, et al. (2009), Goh, (2012), Koontz, Thomas, (2012), Kattel, Cepilovs, et al. (2013), Spano, (2009), De Waal, (2010), Lewandowski, (2018), Mendes, Santos, et al. (2012), Lundberg, et al. (2009), Mwita, (2000).

3 Poister, Pasha, et al. (2013), Sun, Van Ryzin, (2014), Campbell, (2015). Gerrish, (2016), Kalgin, (2016), Cepiku, Hinna, et al. (2017), Lee, McGuire, et al. (2018), Pasha, (2018).

${ }^{4}$ Gudelis (2009), Lockwood (2010), Jong (2015), Verheijen, Dobrolyubova (2007), Dvorak (2010), Bouckaert, Nakrošis, Nemec (2011), Kaselis (2013), Veselý (2013), Sorin (2015), Rauleckas, Nakrošis, et al. (2016), Yakusheva (2017).
} 
represent different interests while managing the territory and have different goals to achieve but Jong (2015) suggests not to concentrate only on the role of policy.

Protected areas in many cases are in close cohesion with municipalities and require specific performance management leading both to sustainability from one side and regional development from the other. Administrations of protected areas are more targeted towards the protection of nature and ecosystems (globally) while municipalities are responsible for the social and economic development of a particular community (locally). Countries and regions try to find solutions in order to find a balance between these contrary requirements of the modern world. The approach of benchmarking as an effective way for learning from good performance practices was discussed by Gerrish (2016). But attempts at benchmarking seem to be a challenge while measuring the performances of different areas (Gunasekaran, 2005). Every protected area differs in institutional set, networks, culture, traditions, communities, etc. Therefore, according to Zope et al. (2019), policies cannot be directly compared across different contexts.

Schleicher, et al. (2018), emphasize the informal aspects of performance management, stating that they are of greater importance than the formal ones. Jong (2015) and Lockwood (2010) argue that a bottom-up implementation of performance management with a high degree of decentralization is more successful. But independent Lithuania, like other post-socialist countries, inherited a strictly hierarchical governing and planning system that followed rigid and standardized procedures of administration for protected areas, partly based on research and monitoring from the scientific community involved. Different protected areas were established without any common policy framework and have to serve the different objectives. Some of these were directed to the protection of the wild nature, others became the centres of tourism. Application of the standardized top-down administrative models in protected areas of developing countries may be problematic for achieving these objectives due to possible conflicts with the local communities and deficits of capacity (Lockwood, 2010).

The system of management in Lithuania's protected territories is very complicated and difficult to be perceived for everyone involved (Juknevičiūtè and Mierauskas, 2012). According to the authors, some issues should be solved before achieving the effectiveness of the management of such territories: i) finding the balance between requirements of stakeholders and nature protection; ii) educating locals to live in cohesion with nature; iii) appropriate financing. Upon accession to the EU, various aspects of performance management (monitoring rules and requirements) were approved by ministerial orders or other legal acts in various areas of public policy in Lithuania (Bučas and Mlinkauskienè, 2011; Gudelis, 2009). The sectoral ministries started to collect a lot of performance information, but the data quality was of a medium level. Municipalities have been involved in the process of collecting and reporting monitoring data, and the burden of data collection has been placed on already overloaded lower-level officials who rarely receive any feedback on how data is being used and whether it is being used at all. This affects the quality of the data, as lower-level civil servants have no desire to engage in routine work, which may be of no use. However, theory teaches: that to maintain the value of protected areas, managers need to monitor the effectiveness of their management actions so that they can identify problems and focus their resources and efforts on addressing these problems (Hockings, 2003). 
Protected areas cover almost 17 percent of Lithuania. The country deals with challenges while organizing the existence on the territories of five national and thirty regional parks. Lithuania has chosen its own way for development of the system of protected areas. Moreover, the authorities at all levels try to find a specific management solution for these territories. However, this is not based on the principles of New Public Governance (Mierauskas, Smalskys, 2013). Independent Lithuania, like other post-socialist countries, inherited a strictly hierarchical governing and planning system that followed rigid and standardized procedures of administration for protected areas, partly based on research and monitoring from the scientific community involved (Yakusheva, 2017).

The most complicated performance management reality has emerged at a national park of the Curonian Spit. This area, unlike the other four national parks in Lithuania, is under the management of two municipalities (Neringa and Klaipeda) and the administration of a national park. The Curonian Spit is inscribed onto the UNESCO world heritage list (together with its Russian part in Kaliningrad oblast). Neringa municipality (which is also a famous Lithuanian and international seaside resort) covers only two percent of the Lithuanian territory of the national park with about 2,500 permanent inhabitants living in four remote settlements. The only Lithuanian sea port, Klaipeda, takes responsibility for Smiltyne suburb, which is a very tiny area at the very end of the spit, separated from the main city by the Curonian lagoon (see Fig.1).

Both municipalities are managed by local council boards while the national park is managed by the administration of the national park. The forests in the area are managed by a division of the State Forest Enterprise. The territory deals with problems of conflict of interest between different authorities and other stakeholders, with the absence of real collaborative management and confrontation of the legislation while trying to find solutions both on the development and protection of the territory. The law helping to facilitate the management of the territory had been discussed recently on an international forum in Neringa.

\section{Figure 1: Lithuanian part of the Curonian Spit from Klaipeda to Nida}

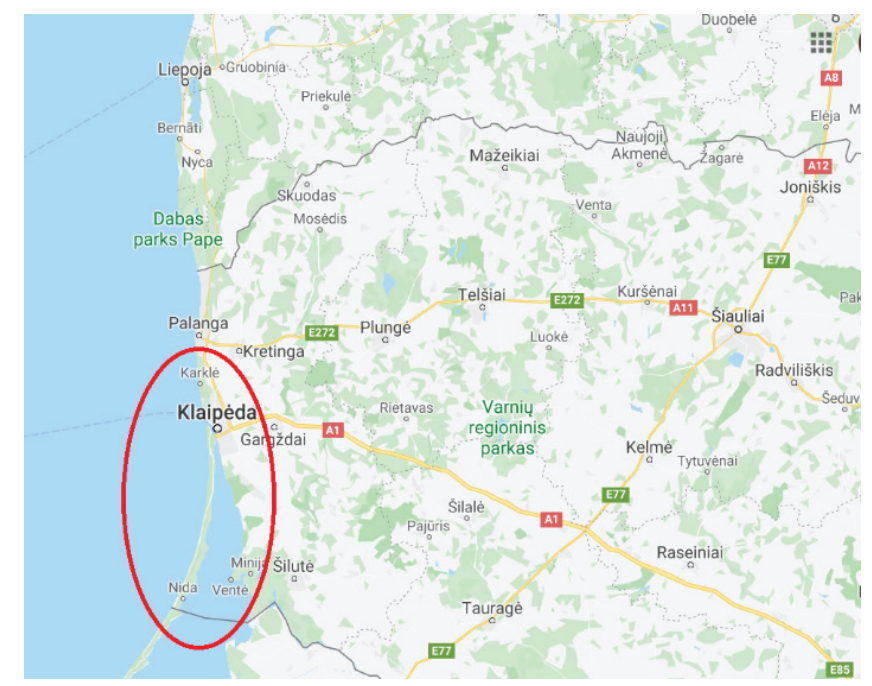

Source: https://www.google.lt/maps/@55.2538256,21.0325986,7.23z 
This research seeks to contribute to the debate concerning the reality of the performance management of the national park. The methodology of the current research was based on qualitative interviews with officials from both municipalities and park administration as well as with local stakeholders. Interviews revealed the challenges of joined-up governance of the territory and provided assumptions of experts on the effectiveness of possible legislation and predictions for improving the performance management of this valuable protected area.

\section{Theoretical framework of performance management}

Performance management has become a tool for governments of contemporary public systems for generating better outcomes for society (Choia \& Moynihanb, 2019; Liu, Wu, Li, Jong \& Sun, 2017). Collaborative performance management based on interagency and intra-agency interactions should be fostered for achieving common goals while sharing the knowledge, skills and all necessary resources (Choia \& Moynihanb, 2019). All stakeholders, locals and indigenous people have to be well informed about and engaged into the development processes (Lockwood, 2010).

The analysis of the current literature (Verbeeten, 2008; Van Dooren et al., 2010) allows for identifying the following purposes of performance management: (i) organizational or policy improvement; (ii) control; (iii) steering; (iv) communication.

Organizational or policy improvement. Strategic planning and the budgeting process are described as long-term and short-term planning, and monitoring can be described as a short-term evaluation. Performance indicators and policy objectives are widely used in policy documents and budgets to ensure the organization$\mathrm{al}$ and policy improvement function, to indicate what activities are expected, what the actions are being performed for and what their costs will be. This purpose requires effective cooperation, coordination and consultation as managers want to improve planning and priority setting (Hockings, 2003).

Control. In order to fulfil the control function, it is necessary to measure the program output, outcomes and impact. Performance management helps to determine whether there is a prerequisite for duplication of programs or whether the program is consistent with other public programs, strategies and conceptions, and to enhance legitimacy and transparency (Nõmm, Randma-Liiv, 2012). These efforts are crucial to the political process, as administrators often do not disrupt programs that have achieved their goals. Fearful of losing financial resources, with loyal and obedient staff they formulate new goals to legitimize the existence of an organization or program. Although performance management should lead to reverse actions, i. e. relocation of resources or revision of contracts with contractors.

Steering. Performance management is the cause of a change in policy decision-making, management, procedures or implementation strategies (Van der Meer, 1999; Murray, 2002). Such performance movement shall be carried out during the preparation or implementation of the program (Stufflebeam, Shinkfield, 2007). It is important to note that performance measurement offers assistance to those responsible for program quality, improvement and/or attention 
to changes in citizens/clients' needs. In other words, performance management can be used to legitimize or "sell" policies, produce desired outcomes and make minor policy adjustments.

Communication. Communication is an important aspect for building a better understanding of performance results between stakeholders, forcing positive change of behavior, earning trust and minimizing negative effects (Fryer, et al., 2009). It is imperative for public sector organizations to use the results of performance measurement in communication with different stakeholder groups. According to Hockings (2003), in the case of a protected area, information can increase the potential of the current study area,particularly that which provides feedback on the strengths and weaknesses of the management. The information received acts on people's knowledge, arguments and advice, and appeals to morality. Properly measured results of the government programs require that intended recipients be provided with quality information on the output of the program (Vedung, 2007; Weiss, 2019). Obviously, communication is not limited only to the transmission of messages, but also covers protection, educational projects, services to members of organizations and also partnership initiatives (Dvorak, Civinskas, 2019).

\section{Materials and Methods}

The motivation for the current research came about after a wide discussion by stakeholders concerning the preparation of a special law for the Lithuanian part of the UNESCO heritage site - the Curonian Spit National Park. The international conference "Curonian Spit (CS) for us and for the world" was held in Nida (the administrative centre of Neringa municipality) last June (2019) under the patronage of the Committee on Culture of the Seimas (Parliament) of the Republic of Lithuania and the organization of the Commission of State Cultural Heritage (National Commission for Cultural Heritage, 2019). Most initiatives have been coming from the state authorities for the protection of the environment and cultural heritage while local stakeholders are not much interested in the issue.

Conferences are not something new in looking for individual ways for the governance of protected areas (Lockwood, 2010; Borrini-Feyerabend, et al. 2012). However, in a classic model of a protected area, its governance was not the case. Such a model is based on the government who makes decisions concerning protected areas (Eagles, Romagosa, Buteau-Duitschaever et. al., 2013). According to Lockwood (2010), Eagles, Romagosa, Buteau-Duitschaever et. al. (2013), indigenous people and park visitors play a key role in the process. But in the case of the Curonian Spit National Park, only a few local stakeholders were interested and attended the conference. As the result, a resolution brought by the Commission of State Cultural Heritage, the administration of the national park of CS and Neringa municipality was addressed to the Lithuanian Seimas with the request to draft a specific law for the entire territory. Cohesion of different interests related to the territory protection, international tourism development and goals of locals as well as division of competences were named as the significant challenges since all 
responsible institutions act on different laws. The resolution emphasised the existence of similar laws for the protection of UNESCO territories around the Globe, but not one single sample was provided during that conference. The aim to present samples of best practice as possible sites for benchmarking was a failure during the conference as well.

According to Jong (2015), performance management does not depend heavily on a policy field. It is important to understand performance management in different and perhaps cross pollinated contexts (Gerrish, 2016). Bottom-up implementation of performance management is more successful with a high degree of professionalism and decentralization (Jong, 2015; Lockwood, 2010). We argue that the incentive in our case has come "top-down", which cannot be perceived as a contemporary democratic approach leading to good governance. Lockwood (2010) states that attempts to apply a top-down model may be problematic in protected areas of developing countries. It is difficult to achieve objectives due to possible conflicts with the local communities and deficits of capacity. Schleicher, et al. (2018) argue that the informal aspects of performance management are of greater importance than the formal ones. But according to Jong (2015), there is a lack of studies making surveys across policy fields.

Benchmarking is also little researched in the case of protected areas. Gunasekaran (2005), Gerrish (2016), Erdil and Erbiyık (2019) argue that the method is appropriate for the measurement and evaluation of best practices at the organizational level. Gerrish (ibid) provides evidence that benchmarking is an effective approach for learning from good performance practises and is a useful element for the setting of performance management from one entity to the other. However, Gunasekaran (2005) sees the difficulties that occur while measuring performances of different areas. Indeed, we argue the policies cannot be directly compared across different contexts (Zope, et al., 2019).

We thus agree that benchmarking is an effective approach but only for identical entities. Apparently, every UNESCO site is a unique and a very complex construct that includes many different aspects. The uniqueness of each UNESCO territory impedes applying specific performance management. Lockwood (2010) emphasises the ability of various combinations of actors that generate diversity of governance as well as different opportunities. Therefore, according to the author, performance management should be suited to the particularities of local conditions and is some kind of experimentation. The benchmarking approach would hardly be useful while arranging a specific regulation in a particular place.

All of the preconditions stated above appeal to possible difficulties in the performance management of the Lithuanian part of the Curonian Spit National Park. This urged us to learn the attitudes of different stakeholders (municipal authorities, representatives of the administration of a national park and representatives of NGOs) in order to reveal the reality of performance management on the Curonian Spit.

Therefore, our research question can be formulated as follows: what difficulties does the performance management of the Curonian Spit deal with and how can the process be improved? 


\section{Methodology}

The approach of comparative analysis helped to reveal the differences in sampled UNESCO sites and to argue that benchmarking from one site to the other is of minimal use. The UNESCO sites of representatives of the conference in Nida (Neringa, LT) were used as sample sites for the analysis. Comparative analysis was based on criteria such as: boundaries of the area, UNESCO criteria, relation to the tourism, problems, management requirements based on regulations, and authorities for protected area management. Criteria were formulated from the subjective point of view of the authors while analysing individual information from every site.

The approach of a qualitative interview with different stakeholders from Klaipeda and Neringa municipalities, and the administration of a national park of the Curonian Spit was held in order to reveal the attitudes of the public decision makers and administrators considering the topic. The "bottom" side was represented by locals from business and social fields. The small number of locals in some cases influence both their occupation and competence in several fields: i.e. the same person may be treated as an indigenous local, a businessman or even a politician; a former civil servant at the administration of the municipality is a current employee at the administration of a national park; a representative of an administration of a national park is a council board member as well as a former vice mayor. These interrelated competences prove the informants to be high-level experts for the interviews. Initial respondents were chosen subjectively relying on personal acquaintances of the authors as there are very few local inhabitants living permanently in Neringa (up to 3000) and Smiltyne (about 40). Other respondents were identified using the 'snowball' method in which the initial contacts from Neringa and Klaipeda suggested additional respondents who in turn suggested others. In total, seven respondents (six from Neringa and one from Klaipeda), who permanently live on the Curonian Spit contributed to the process. Additionally, one expert from the administration of Klaipeda city municipality was interviewed. The advice of that expert led us to reject the idea of interviewing politicians from the Klaipeda council board. We were informed that they are not engaged in the problems of the Curonian Spit.

The interview survey was designed and administered by the authors following Lockwood's (2010) proposal to use a suitable qualitative methodology. The structure of the interview was adapted from Lockwood's framework of good governance for protected areas (see Lockwood, 2010). Lockwood defined seven principles for good governance of a protected area: legitimacy, transparency, accountability, inclusiveness, fairness, connectivity and resilience. According to the author, in following these principles in coherence with ethics and rationality, one may reach management effectiveness.

The choice of Lockwood's framework was based on the following criteria: (i) the framework was created in the context of public sector performance management; (ii) the framework integrates the principles of the sustainable governance of protected areas; (iii) the validity of it was tested by using a Delphi survey (Shields, Moore \& Eagles, 2016).

Lockwood (2010, p. 759), in his work, pointed out that reporting (as an essential element of transparency) may serve as a basis for accountability. This statement refers to some correlation between two principles: transparency and account- 
ability. The author also mentioned logical relations between the principles of inclusiveness and coordination (as requirements for connectivity) when describing the inclusion of local, regional, national and international interests for a "system wide design" (Lockwood, 2010, p. 760).

Considering the author's notes above, we joined some of these seven principles and made the main interview section by grouping questions into five categories: i) legitimacy; ii) inclusiveness and connectivity; iii) transparency and accountability; iv) fairness; and v) resilience. The semi structured interview questionnaire totalling 18 questions was made with two introductory (the structure of the document and sub statutory acts) and two finalization questions (the need of adaptive strategy and who would lead preparation and coordination of that strategy; possibility of reaching a joint development conception with the Russian part of the CS). All of the questions for the main interview part were adopted from Lockwood's statements relating to each principle (see Table 1). The interviews were conducted in Lithuanian and the results were interpreted into English.

Table 1

\section{Summary of issues raised in the interview survey by issue and theme}

\begin{tabular}{|c|c|}
\hline Thematic Group & Themes focused \\
\hline $\begin{array}{l}\text { Introductory } \\
\text { questions }\end{array}$ & $\begin{array}{l}\text { 1. Structure of the law } \\
\text { 2. Sub statutory legal acts }\end{array}$ \\
\hline Legitimacy & $\begin{array}{l}\text { 3. Institutional background } \\
\text { 4. Governance modelling } \\
\text { 5. Local communities in the governance model } \\
\text { 6. Functional integration }\end{array}$ \\
\hline $\begin{array}{l}\text { Inclusiveness and } \\
\text { Connectivity }\end{array}$ & $\begin{array}{l}\text { 7. Horizontal and vertical networking } \\
\text { 8. Coordination of the network } \\
\text { 9. Trade off and balancing among all stakeholders } \\
\text { 10. Development and protection }\end{array}$ \\
\hline $\begin{array}{l}\text { Transparency and } \\
\text { Accountability }\end{array}$ & $\begin{array}{l}\text { 11. Transparency (communication about the making decision process since } \\
\text { beginning till the end) } \\
\text { 12. Accountability (downwards; answerability; constituents rights to express } \\
\text { approval/ disapproval) }\end{array}$ \\
\hline Fairness & $\begin{array}{l}\text { 13. Recognition of human, civil and indigenous rights } \\
\text { 14. Respect to the wider interests of national and international bodies }\end{array}$ \\
\hline Resilience & $\begin{array}{l}\text { 15. Control, autonomy and flexibility } \\
\text { 16. Balancing between development and security for sustainability through: } \\
\text { - HR education and innovation } \\
\text { - sharing finances } \\
\text { - sharing infrastructure } \\
\text { - implementation of common projects } \\
\text { - compensation for imposition of costs } \\
\text { - protection of all ecosystems }\end{array}$ \\
\hline Finalization & $\begin{array}{l}\text { 17. Demand for adaptation strategy; coordination of its implementation } \\
\text { 18. Trends for partnership in common development with administration } \\
\text { of a Kurshskaja Kosa National Park (KKNP), Russian Federation }\end{array}$ \\
\hline
\end{tabular}




\section{Findings}

Different stakeholders gain useful knowledge by participating in international projects, conferences, etc. The conference speakers in Nida represented five UNESCO heritage sites (see Table 2). All of these territories are situated in national parks. The participants - with the exception of those from Kurshskaja Kosa National Park in the Russian Federation - and hosts represented practices from the Western Europe context.

\section{Table 2}

\section{UNESCO heritage sites}

\begin{tabular}{|l|l|}
\hline \multicolumn{1}{|c|}{ UNESCO territory } & \multicolumn{1}{|c|}{ Definition } \\
\hline English Lake District (ELD) & $\begin{array}{l}\text { Mountainous area in northwest England. Modelled } \\
\text { by glaciers in the Ice Age and shaped by an agropastoral } \\
\text { land use system (fields enclosed by walls). Combined } \\
\text { work of nature and human activity has produced } \\
\text { a harmonious landscape. }\end{array}$ \\
\hline $\begin{array}{l}\text { Portovenere, Cinque Terre } \\
\text { as well as Palmaria, Tino and Tinetto } \\
\text { islands (CT) }\end{array}$ & $\begin{array}{l}\text { An example of a "cultural, evolved organic landscape". } \\
\text { The eastern Ligurian coast (15 km) between Cinque Terre } \\
\text { and Portovenere is a cultural landscape of great scenic } \\
\text { and cultural value. The layout and disposition of the small } \\
\text { towns and the shaping of the surrounding landscape, } \\
\text { overcoming the disadvantages of a steep, uneven terrain. } \\
\text { The islands are noteworthy for the natural beauty and } \\
\text { for the remains of early monastic establishments. }\end{array}$ \\
\hline Serra de Tramuntana (ST) & $\begin{array}{l}\text { The cultural landscape of Sera de Tramuntana located } \\
\text { on a sheer-sided mountain range parallel to the north- } \\
\text { western coast of the island of Mallorca. ST constitutes } \\
\text { a significant example of Mediterranean agricultural } \\
\text { landscape which, after centuries of transformations } \\
\text { of the steep terrain morphology, has been made productive } \\
\text { and well-adapted to human settlement. }\end{array}$ \\
\hline Curonian Spit (CS) & $\begin{array}{l}\text { The site covers the Dutch Wadden Sea Conservation Area, } \\
\text { the German Wadden Sea National Parks of Lower Saxony } \\
\text { and Schleswig-Holstein, and most of the Danish Wadden } \\
\text { Sea maritime conservation area. A National Park. }\end{array}$ \\
\hline $\begin{array}{l}\text { Wadden Sea (Denmark, the Netherlands } \\
\text { and Germany) (WS) }\end{array}$ & $\begin{array}{l}\text { Sand dune peninsula, 98 km long and from 0.4 to } 4 \text { km wide. } \\
\text { The CS is situated in the CS National Park in Lithuania } \\
\text { and the Kurshskaja Kosa National Park of the Russian } \\
\text { Federation }\end{array}$ \\
\hline \multirow{2}{*}{ and }
\end{tabular}

The conference speakers emphasised the main issues and shared valuable information concerning the protected areas they represented. Systematic analysis of these speeches as well as the data on UNESCO web sites highlighted the differences existing in every single case and helped to systemize the challenges of the respective sites while managing the performance of these territories (see Table 3). Protected areas may cover the territory within a single country or unite several of them. All respective areas also face issues related to tourism. 


\section{Aspects of managing protected territories}

\begin{tabular}{|c|c|c|c|}
\hline $\begin{array}{l}\text { Boun- } \\
\text { daries }\end{array}$ & $\begin{array}{l}\text { Site, } \\
\text { criteria }\end{array}$ & Challenges & Tourism \\
\hline \multirow{3}{*}{ 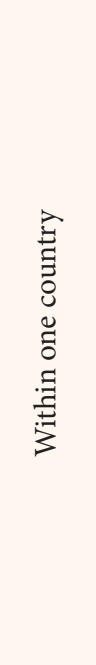 } & $\begin{array}{l}\text { ELD } \\
\text { (ii), (v) }\end{array}$ & $\begin{array}{l}\text { Prevention of impact of climate change; } \\
\text { economic pressure on traditional } \\
\text { agro-farming }\end{array}$ & $\begin{array}{l}\text { To decrease pressure from } \\
\text { tourism }\end{array}$ \\
\hline & $\begin{array}{l}\text { CT } \\
\text { (ii), (iv), (v) }\end{array}$ & $\begin{array}{l}\text { Protection of the property and } \\
\text { landscape (authenticity of the } \\
\text { settlements) from changes and damages } \\
\text { made by floods and restoration as well } \\
\text { as from the impact of the modern } \\
\text { socio-economic development. } \\
\text { Supporting farmers to add value to their } \\
\text { traditional methods and materials } \\
\text { in order to sustain livelihoods and } \\
\text { the landscape }\end{array}$ & $\begin{array}{l}\text { To employ mechanisms for } \\
\text { linking tourism activity and } \\
\text { landscape maintenance activation } \\
\text { and programs for the reclamation } \\
\text { of the terraced landscape to allow } \\
\text { recovery of some tens of hectares } \\
\text { to vines and olive cultivation }\end{array}$ \\
\hline & $\begin{array}{l}\text { ST } \\
\text { (ii), (iv), (v) }\end{array}$ & $\begin{array}{l}\text { Protection from development } \\
\text { pressures of increasing tourism. Better } \\
\text { monitoring of property in the highly } \\
\text { populated buffer zone }\end{array}$ & $\begin{array}{l}\text { To protect from the progressive } \\
\text { increase of tourism that leads } \\
\text { to a decline in traditional } \\
\text { dynamic processes }\end{array}$ \\
\hline \multirow[b]{2}{*}{ 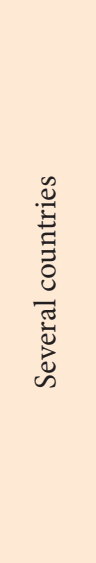 } & $\begin{array}{l}\text { WS } \\
\text { (viii), (ix), (x) }\end{array}$ & Protection of natural ecosystems & $\begin{array}{l}\text { To develop sustainable tourism } \\
\text { as tourism creates the majority } \\
\text { of employment }\end{array}$ \\
\hline & $\begin{array}{l}\text { CS } \\
(\mathrm{v})\end{array}$ & $\begin{array}{l}\text { Regulation of the number of visitors } \\
\text { to the property; regulation of new } \\
\text { developments and other economic } \\
\text { activities in order to avoid any } \\
\text { irreversible changes. Maintenance } \\
\text { of fishermen's houses. } \\
\text { Coordination of actions between } \\
\text { the states in order to protect the } \\
\text { Outstanding Universal Value of the } \\
\text { property. Preparation of an integrated } \\
\text { Management Plan with the Tourism } \\
\text { management Plan included }\end{array}$ & $\begin{array}{l}\text { To regulate the number of visitors } \\
\text { (tourists) to the property and new } \\
\text { developments related to tourism. } \\
\text { To prepare an integrated Tourism } \\
\text { Management Plan for the entire } \\
\text { territory }\end{array}$ \\
\hline
\end{tabular}

The respective sites unanimously strive to prevent negative impacts of tourism and modern socio-economic development while managing their territories. An individual set of UNESCO criteria also commits every site to determine different legislation and unique management strategies for the performance of management accordingly. The variety of site authorities responsible for corresponding rules and laws in each of these sites is numerous (with variation from 2 in ELD to 5 in CS). Different combinations of actors generate diversity of governance as well as different opportunities (Lockwood, 2010). Also, such a variation both in authorities and legislation on a single territory makes performance management complicated and no less challenging.

In agreement with Zope et al. (2019), the same policies cannot be directly applied from one context to the other. The uniqueness of the site, different UNESCO criteria, and diversity in authorities and regulations are some of the obstacles 
for any benchmarking while drawing up specific legislation for the management of a particular protected territory. In our case, none of the interviewed experts has seen or read any similar law in practice. Two of them mentioned that Riga old town has a specific regulation but their law, therefore, cannot be benchmarked as Riga fulfills a different set of UNESCO criteria ( $i$ and ii) and, thus, has different requirements for protection and development.

The interview outcomes reflect the expressed ideas and thoughts of experts concerning performance management of the Curonian Spit. During some of the interviews some uncertainty and wariness was felt while expressing personal opinions, especially by those employed in a public sector.

The respondents of qualitative interviews agreed that a new regulation in a form of a sub statutory document would be a good supplement, if only it could clarify and divide overlapping responsibilities and competencies of institutions acting on the site. Lack of appropriate attitude from the state government, lack of finances, and lack of understanding of the value and importance of this area at the national level were mentioned as the most serious issues. These issues are similar to those expressed by Juknevičiūtè and Mierauskas (2012). Actually, respondents scarcely believe that any law would help to change the everyday situation and lead to the better management of the site, or help to solve the issues of locals and their social problems.

Therefore, all of the interviewees agree that a common strategy for the development of the territory would be very beneficial. Requirements for the preparation of such a strategy should be set in the new regulation. The common development strategy might solve serious issues based on the lack of approaches for assessing the qualitative implementation of performance on the national park of Curonian Spit. A quick scan of the performance report for 2019 provides some evidence that the national park administration has difficulties with qualitative indicators of performance. For instance, 14 training programmes were organized for $25 \mathrm{em}$ ployees of the organization; cooperation with a number of institutions, NGOs and other partners have also been reported (Directorate of Kursiu Nerija National Park, 2020). Indeed, the report is based only on quantitative results. This confirms what was reported by the National Audit Office of Lithuania (2019): <... "the indicators are formed as a list of everything that can be counted" $<. . .>$ "counting meetings, events, participants, employees participating in training, but we do not measure performance" $<\ldots>$.

Responsibility for the development of the strategy would lie with the newly established Board of competent experts that represent all stakeholders living and performing on the Curonian Spit. The idea of new consultative bodies is not new. This was proposed by Yakusheva (2017) in the cases of Poland and Slovakia. According to her research, such consultative bodies will serve as "transparent platforms and contribute to the establishing trust in park administrations" (Yakusheva, 2017). However, the effectiveness of the board would depend on delegated competencies.

Actually, the best outcome could be achieved in cooperation with the Russian part of the Spit. But despite the requirement to prepare a common UNESCO site management plan, still nothing happens as no cooperation with institutions from 
the neighbouring side of the Spit is possible at the moment. The main problems to consider are: i) issues of an outer EU border; ii) different policies for development; iii) different attitudes to and protection of the traditions of the indigenous people; iv) different territorial structures of national parks (inclusion/exclusion of settlements); v) differences in legislation.

Responses to the main part were systemised and analysed following each category of the questionnaire in order to receive a clear picture not only of the difficulties or restrictions for the good performance management of the Curonian Spit, but also to reveal possibilities for its improvement (see Table 4).

Table 4

\section{Difficulties and possibilities for good governance in the Curonian Spit (Lithuania)}

\begin{tabular}{|c|c|c|}
\hline Principles & Difficulties & Possibilities \\
\hline \multirow[t]{3}{*}{ Legitimacy } & $\begin{array}{l}\text { Very complicated structure } \\
\text { with overlapping competences }\end{array}$ & $\begin{array}{l}\text { Revision (audit) of institutional competences as a must } \\
\text { Establishment of a new body - Board of stakeholders - } \\
\text { responsible for development issues } \\
\text { Providing more power to municipal authorities }\end{array}$ \\
\hline & $\begin{array}{l}\text { Scepticism on higher } \\
\text { engagement of locals } \\
\text { (treating them as immature) } \\
\text { into process management }\end{array}$ & $\begin{array}{l}\text { Clear definition of a "real local inhabitant" } \\
\text { Education of community members and preparing } \\
\text { them for engagement into the governance } \\
\text { Local decision makers learning how to integrate } \\
\text { locals and discuss before making any decisions }\end{array}$ \\
\hline & $\begin{array}{l}\text { No functional integration } \\
\text { of institutions on the site }\end{array}$ & $\begin{array}{l}\text { Revision of existing network; requirement } \\
\text { for the networking should be set in a law } \\
\text { Engagement of locals after education } \\
\text { Professional moderation of integral functioning } \\
\text { Education of all involved to work integrally }\end{array}$ \\
\hline \multirow[t]{7}{*}{$\begin{array}{l}\text { Inclusiveness } \\
\text { and } \\
\text { Connectivity }\end{array}$} & $\begin{array}{l}\text { No engagement } \\
\text { of communities into the } \\
\text { network }\end{array}$ & $\begin{array}{l}\text { Improvement of the network involving all } \\
\text { stakeholders at all levels }\end{array}$ \\
\hline & $\begin{array}{l}\text { Vertically: remote governments } \\
\text { not willing to cooperate }\end{array}$ & $\begin{array}{l}\text { Developing close cooperation vertically } \\
\text { and horizontally for bridging the gap }\end{array}$ \\
\hline & $\begin{array}{l}\text { Horizontally: cooperation based } \\
\text { on the goodwill of the leaders }\end{array}$ & $\begin{array}{l}\text { Appointment of real (professional) leaders } \\
\text { to manage respective institutions }\end{array}$ \\
\hline & Absence of real coordination & $\begin{array}{l}\text { Coordinating by: i) competent representatives } \\
\text { from Neringa or Klaipeda municipalities; } \\
\text { ii) independent Board of stakeholders with } \\
\text { the leadership of the Ministry of Justice; } \\
\text { iii) national secretariat of UNESCO }\end{array}$ \\
\hline & \multirow{3}{*}{$\begin{array}{l}\text { More restrictions and } \\
\text { regulation of nature protection } \\
\text { than support for locals in their } \\
\text { style of life }\end{array}$} & $\begin{array}{l}\text { Balancing of severe attitudes as well as trade-offs } \\
\text { should be set as regulations }\end{array}$ \\
\hline & & $\begin{array}{l}\text { Discussions of all stakeholders in order to reach } \\
\text { common agreements concerning the development } \\
\text { and protection of ecosystems }\end{array}$ \\
\hline & & $\begin{array}{l}\text { Announcements by leaders of the reasons to protect } \\
\text { the site and what benefit locals receive from that site }\end{array}$ \\
\hline
\end{tabular}




\begin{tabular}{|c|c|c|}
\hline Principles & Difficulties & Possibilities \\
\hline $\begin{array}{l}\text { Transparency/ } \\
\text { Accountability }\end{array}$ & $\begin{array}{l}\text { Wrong understanding } \\
\text { of transparency and } \\
\text { accountability }\end{array}$ & $\begin{array}{l}\text { Setting principles of transparency and accountability } \\
\text { as regulations } \\
\text { Steps to do: i) learn how to implement transparency } \\
\text { and accountability; ii) develop effective communication } \\
\text { channels able to regulate huge information flows } \\
\text { and iii) collect and process information }\end{array}$ \\
\hline Fairness & $\begin{array}{l}\text { Interpretations of human, } \\
\text { civil and indigenous rights; } \\
\text { signs of archaic development }\end{array}$ & $\begin{array}{l}\text { Setting formulations of human and indigenous } \\
\text { rights in a regulatory document, despite having } \\
\text { inscriptions in a LR Constitution } \\
\text { Educating society that we have not only rights but } \\
\text { duties as well }\end{array}$ \\
\hline \multirow[t]{3}{*}{ Resilience } & $\begin{array}{l}\text { No balance between strict } \\
\text { control and flexibility }\end{array}$ & $\begin{array}{l}\text { Setting a strict control on the principal agreements } \\
\text { concerning the development and protection } \\
\text { of the site (framework). } \\
\text { Setting slight flexibility and autonomy within } \\
\text { that framework following common sense and } \\
\text { human logic } \\
\text { Acquiring the maturity to employ wide flexibility }\end{array}$ \\
\hline & $\begin{array}{l}\text { Lack of detailed sustainability } \\
\text { requirements for the site }\end{array}$ & $\begin{array}{l}\text { Setting requirements for sustainability } \\
\text { in a regulatory document } \\
\text { Strengthening partnership through implementing } \\
\text { common projects } \\
\text { Higher engagement of Smiltyne community into } \\
\text { the site management process } \\
\text { Increasing the role of Klaipeda municipality and } \\
\text { Klaipeda Regional Board }\end{array}$ \\
\hline & $\begin{array}{l}\text { Weak understanding } \\
\text { of sustainability }\end{array}$ & $\begin{array}{l}\text { Fostering innovations and sharing knowledge } \\
\text { for experimenting novelties for protection and } \\
\text { development of the site. } \\
\text { Learning how to share knowledge, finances and } \\
\text { infrastructure in order to increase synergy and } \\
\text { economies of scale on the site } \\
\text { Partial compensation of expenses for locals helping } \\
\text { them to continue living a traditional style of life } \\
\text { Informing the purpose of such compensation - } \\
\text { protection of traditional property as well } \\
\text { as traditions and other ecosystems on the site }\end{array}$ \\
\hline
\end{tabular}

The experts named many difficulties in good performance management. Problems of good governance were listed in every category with the minority in Transparency and Accountability as well as in Fairness. Most issues related to: i) the management and coordination of the institutions on the site in terms of networking, ii) revision of rights of locals and their engagement into performance management, iii) integration of aspects of sustainability, and iv) improving information channels. But respondents of qualitative interviews provided various useful proposals for improvement as well. Many of them should be set as regulations in legislation: requirements for sustainability; framework of general control; slight flexibility as well as autonomy within the frame of restrictions; and clear definitions of human and indigenous rights. 
Education, learning and knowledge sharing were possibilities expressed most and repeatedly mentioned in four of the five categories (with the exception of Inclusiveness and Connectivity). The interviewees suggested different audiences and topics for education: i) society - before their engagement into the network cooperation; ii) decision makers - how to integrate locals and discuss with them; iii) all involved - how to work integrally, how to share knowledge, finances and infrastructure, and how to foster innovations.

Networking was the second most important aspect named by experts. Proposals to revise existing networks as well as institutional competencies before improvement were expressed. The outcome of re-networking should lead to the balancing of different attitudes and inclusion of all stakeholders vertically and horizontally. Professional coordination of the network by real leaders (competent representatives from various stakeholder groups) is important for developing close cooperation and bridging the gap. Other proposals related to improving network cooperation were as follows: i) establishment of a Board of stakeholders; ii) providing more power for municipal authorities with increased engagement of Klaipeda municipality (and Smiltyne in particular) and active participation of Klaipeda Regional Board. However, the statutory increase in the powers of municipalities is not enough. Local self-government can only function effectively while having sufficient funds for performing functions at its disposal (Burbulyte-Tsiskarishvili, Dvorak, et. al., 2018).

The last but not least aspect for good performance management on the site is a particular attitude to the locals. First of all, a clear definition of a status of "local" is necessary. Also, development of communication channels for managing complex information and announcements to the community is necessary. Locals should receive understandable information concerning requirements for sustainable development as well as the clearly expressed responsibilities they have regarding environmental protection. Changes are made in the sentence with insertion of "their" and deletion of the ending of the sentence. A very clear explanation of what benefit they receive while living in the national park should be articulated too.

\section{Conclusions and limitations}

According to Lockwood (2010), possible conflicts with locals and deficits of capacity may be treated as obstacles for good governance and performance management in protected areas of developing countries in particular. Kim \& Hong (2013) emphasized three dimensions: political, legal and social - as important for successful performance management. Performance management should not be influenced by political or leadership change. Systemic continuity should be set on a legal basis. Citizens' awareness and satisfaction helps in building public trust. In our case, we see that the experts would be willing to exclude real engagement by locals and indigenous people from decision making and governance, thus treating them too immaturely. Therefore, a lack of knowledge of modern governing systems and performance based only on the goodwill of the leaders generates possible conflicts in the performance management of the Curonian Spit National Park.

Western European countries have long-lasting experience in the performance management of protected territories and have developed tough cooperation among 
various stakeholders. Countries of new democracies need to find their personal ways for performance management as benchmarking is not an appropriate approach due to various reasons: i) every site is unique and influenced by many different aspects; ii) cooperation for united performance management between countries or municipalities is hard to be employed due to specific policy or lack of political attitude. The case of the site of Curonian Spit may prove such statements with the example of the Neringa municipality that has both economic peculiarity (Bučaitè-Vilkè, Civinskas et. al, 2019) and overall exceptionality (Pociūtè, 2012).

In the theoretical part of this study we argue four purposes of performance management: (i) organizational or policy improvement; (ii) control; (iii) steering; (iv) communication. The outcome of the survey revealed that all of these should be kept in mind in the case of the Curonian Spit. Re-arrangement of the institutional network should follow higher inclusiveness, communication and change in intercountry policy. The expressed problems in controlling and steering should be solved.

First of all, the necessity of a common strategy unifying all (sometimes overlapping) aims was proposed. The purpose of controlling and steering should appeal to the needs of citizens and directly to adjustment of the policies so that they become easy "to sell", to indigenous locals in particular as they play a key role in the process (Lockwood, 2010). In our case, the control should be set as regulation with slight flexibility and autonomy allowed within the frame of restrictions (until the maturity of locals).

Kim \& Hong (2013) argue the role of leadership (in terms of official leader) for effectiveness of performance management. Professional and very competent leaders having not only "goodwill" but also a clear understanding of performance management should steer (or manage) both the strategy and the network as one complex system.

Flattening the network and reaching good performance management largely depends on informal factors (Schleicher, et al., 2018). In agreement with Lockwood (2010), the difficulties to achieve objectives in top-down models occur due to possible conflicts with the local communities. Therefore communication and information in the form of advice may force a positive change of behaviour and appeal to the morality of stakeholders acting on the site. The education of all concerned, learning and knowledge sharing, play an important role in the development of every modern society and should be treated as a valuable approach for setting and improving performance management in such complex territories as we have in the Curonian Spit.

The methodology of interview from this work may be used for similar works with some adaptation in consideration of the specifications of the protected area. Several questions in some cases may be removed from the questionnaire or unified into a single position. We agree with Jong (2015) and Gerrish (2016) that not many surveys are done across policy fields. In addition, the argument of Zope, et al. (2019) that policies cannot be directly compared across different contexts, needs further research. In our case, only the sites of attendants of the conference in Nida were compared in order to prove the uniqueness of each of them. More areas could be compared in order to better prove our findings. This is one of the limitations of our work. The small number of experts interviewed from limited representation areas is the second limitation. Interviewees from Klaipeda municipality and state institutions would reveal a more complex spectrum of the topic, but this might exceed the aims of this article. 


\section{REFERENCES}

1. Boland, T. \& Fowler, A. (2000). A Systems Perspective of Performance Management in Public Sector Organisations. International Journal of Public Sector Management, vol. 13, no 5, pp. 417-446.

2. Borrini-Feyerabend, G., Johnston, J. \& Pansky, D. (2012). Governance of Protected Areas. In: Managing Protected Areas, pp. 146-175. Routledge.

3. Bouckaert, G. \& Halligan, J. (2007). Managing Performance: International Comparisons. Routledge: London and New York.

4. Bouckaert, G., Nakrošis, V. \& Nemec, J. (2011). Public Administration and Management Reforms in CEE: Main Trajectories and Results. NISPAcee Journal of Public Administration and Policy, vol. 4, no 1, pp. 9-29.

5. Bučas, J. \& Mlinkauskienè, A. (2011). Vietos gyventojų požiūrio ị statybinị paveldą saugomose teritorijose vertinimas. Gimtasai kraštas [Assessment of Local Residents' Attitude Towards the Built Heritage in Lithuanian Protected Areas]. Vol. 4, p. 29-34. Available at: https://etalpykla. lituanistikadb.lt/object/LT-LDB-0001:J.04 2011 1367180557343/ (accessed: 21 April, 2020).

6. Bučaitė-Vilkè, J., Civinskas, R., Lazauskienè, A., Leščauskaitė, V., Lackowska, M., Gendźwiłł, A., Krukowska, J. \& Mikalauskas, A. (2019). Savivaldybiu bendradarbiavimas Lietuvoje: formos, galimybes, vizijos: kolektyvine monografija [Cooperation of Municipalities in Lithuania: forms, possibilities, visions: collective monograph]. VDU: Kaunas.

7. Burbulytė-Tsiskarishvili, G., Dvorak, J. \& Žernytė, A. (2018). Savivaldybių funkcijų ir galių kaita Lietuvoje 1994-2016 metais [Changes of Local Functions and Local Powers in Lithuania 1994-2016]. Viešoji politika ir administravimas, vol. 17, no 3, pp. 399-420.

8. Campbell, J.W. (2015). Identification and Performance Management: An Assessment of Change-Oriented Behavior in Public Organizations. Public Personnel Management, vol. 44, no 1 , pp. 46-69.

9. Cepiku, D. (2017). Performance Management in Public Administrations. TR Klassen, D. Cepiku, T.J. Lah (Eds.), Handbook of global public policy and administration. Oxon \& New York: Routledge.

10. Cepiku, D., Hinna, A., Scarozza, D. \& Savignon, A. B. (2017). Performance Information Use in Public Administration: An Exploratory Study of Determinants and Effects. Journal of Management \& Governance, vol. 21, no 4, pp. 963-991.

11. Choia, I. \& Moynihanb, D. (2019). How to Foster Collaborative Performance Management? Key Factors in the US Federal Agencies. Public Management Review, vol. 21, no 10, pp. 1538-1559.

12. De Waal, A.A. (2010). Achieving High Performance in the Public Sector: What Needs to be Done? Public Performance \& Management Review, vol. 34, no 1, pp. 81-103.

13. Directorate of Kursiu Nerija National Park (2020). Kuršių nerijos nacionalinio parko direkcijos 2019 metu veiklos ataskaita [Performance report of the Curonian Spit National Park Authority in 2019]. Available: http://nerija.am.lt/VI/files/File/2020/KNNPd_ataskaita_2019.pdf (accessed: 21 April, 2020).

14. Dvorak, J. (2010). Evaluation of the European Union Structural Funds' Support in Poland: Scope and Significance. Baltic Journal of Law \& Politics, vol. 3, no 1, pp. 53-75.

15. Dvorak, J. \& Civinskas, R. (2019). The Sweden Model of Information Exchange and Partnership between Stakeholders: The Case of Posting Workers. Public administration issues, vol. 1, pp. 190-210. 
16. Eagles, P. F., Romagosa, F., Buteau-Duitschaever, W. C., Havitz, M., Glover, T. D. \& McCutcheon, B. (2013). Good Governance in Protected Areas: An Evaluation of Stakeholders' Perceptions in British Columbia and Ontario Provincial Parks. Journal of Sustainable Tourism, vol. 21, no 1, pp. 60-79.

17. Erdil, A. \& Erbiyık, H. (2019). The Importance of Benchmarking for the Management of the Firm: Evaluating the Relation between Total Quality Management and Benchmarking. Procedia Computer Science, no 158, pp. 705-714.

18. Fryer, K., Antony, J. \& Ogden, S. (2009). Performance Management in the Public Sector. International Journal of Public Sector Management, vol. 22, no 6, pp. 478-498.

19. Gerrish, E. (2016). The Impact of Performance Management on Performance in Public Organizations: A Meta-Analysis. Public Administration Review, vol. 76, no 1, pp. 48-66.

20. Goh, S. C. (2012). Making Performance Measurement Systems More Effective in Public Sector Organizations. Measuring Business Excellence, vol. 16, no 1, pp. 31-42.

21. Gudelis, D. (2009). Lietuvos savivaldybiu veiklos matavimo būklès vertinimas [Assessment of the Status of Performance Measurement of Lithuanian Municipalities]. Viešoji Politika ir Administravimas, no 29, pp. 91-98.

22. Gunasekaran, A. (2005). Benchmarking in Public Sector Organisations. Benchmarking: International Journal, vol. 12, no 4, pp. 289-92.

23. Hockings, M. (2003). Systems for Assessing the Effectiveness of Management in Protected Areas. BioScience, vol. 53, no 9, pp. 823-832.

24. Jong, M. (2015). The Impact of Performance Management on Performance in Public Organizations: Negligible yet Increasing? Public Administration Review, vol. 76, no 1, pp. 67-68.

25. Juknevičiūtè, A. \& Mierauskas, P. (2012). Saugomų teritorijų plètra Lietuvoje: valdymo iššūkiai. Darnaus vystymosi strategija ir praktika [Development of Protected Areas in Lithuania: Management Challenges], vol. 1, no 6, pp. 78-92. Available: https://etalpykla.lituanistikadb.lt/object/LT-LDB-0001:J.04 2012 1370506866539/ (accessed: 21 April, 2020).

26. Kalgin, A. (2016). Implementation of Performance Management in Regional Government in Russia: Evidence of Data Manipulation. Public Management Review, vol. 18, no 1, pp. 110-138.

27. Kattel, R., Cepilovs, A., Drechsler, W., Kalvet, T., Lember, V. \& Tõnurist, P. (2013). Can We Measure Public Sector Innovation? A literature review. LIPSE Project Working Paper, no 2.

28. Kaselis, M. (2013). Development of Performance Management Reforms in Lithuanian Public Sector. Baltic Journal of Law \& Politics, vol. 6, no. 2, pp. 50-74.

29. Kim, P.S. \& Hong, K.P. (2013). Major Constraints and Possible Solutions for Performance Management in Korea. Public Management Review, vol. 15, no 8, pp. 1137-1153. Available: DOI: 10.1080/14719037.2013.818844 (accessed: 21 April, 2020).

30. Koontz, T.M. \& Thomas, C.W. (2012). Measuring the Performance of Public-Private Partnerships: A Systematic Method for Distinguishing Outputs from Outcomes. Public Performance \& Management Review, vol. 35, no 4, pp. 769-786.

31. Lee, D., McGuire, M. \& Kim, J.H. (2018). Collaboration, Strategic Plans and Government Performance: The Case of Efforts to Reduce Homelessness. Public Management Review, vol. 20, no 3, pp. 360-376.

32. Liu, L., Wu, T., Li, S., Jong, M. \& Sun, M. (2017). The Drivers of Local Environmental Policy in China: An Analysis of Shenzhen's Environmental Performance Management System, 2007-2015. Journal of Cleaner Production, no 165, pp. 656-666. 
33. Lewandowski, M. (2018). Refocusing Performance Management through Public Service Design? In: Cross-Sectoral Relations in the Delivery of Public Services, pp. 1-21. Emerald Publishing Limited.

34. Lin, J.S., \& Lee, P.Y. (2011). Performance Management in Public Organizations: A Complexity Perspective. International Public Management Review, vol. 12, no 2, pp. 81-96.

35. Lockwood, M. (2010). Good Governance for Terrestrial Protected Areas: A Framework, Principles and Performance Outcomes. Journal of Environmental Management, vol. 91, pp. 754-766.

36. Lundberg, K., Balfors, B. \& Folkeson, L. (2009). Framework for Environmental Performance Measurement in a Swedish Public Sector Organization. Journal of Cleaner Production, vol. 17, no 11, pp. 1017-1024.

37. Mendes, P., Santos, A. C., Perna, F. \& Teixeira, M. R. (2012). The Balanced Scorecard as an Integrated Model Applied to the Portuguese Public Service: A Case Study in the Waste Sector. Journal of Cleaner Production, no 24, pp. 20-29.

38. Micheli, P. \& Mari, L. (2014). The theory and Practice of Performance Measurement. Management Accounting Research, vol. 25, no 2, pp. 147-156.

39. Mierauskas, P. \& Smalskys, V. (2013). Saugomų teritorijų sistemų organizavimo principai viešojo valdymo kontekste [Principles of Organization of the Protected Area System in the Context of New Public Governance]. Viešoji politika ir administravimas, vol. 12, no 2, pp. 236-247.

40. Murray, R. (2002). Citizens Control of Evaluation: Formulating and Assessing Alternatives. Evaluation, vol. 8, no 1, pp. 81-100.

41. National Audit Office of Lithuania (2019). Strateginio planavimo ir biudžeto formavimo pokyčių vertinimas [Evaluation of Changes in Strategic Planning and Budgeting]. Available at: https://www.vkontrole.lt/pranesimas_spaudai.aspx?id=24997 (accessed 21, April, 2020).

42. National Commission for Cultural Heritage (2019). The Parliament of the Republic of Lithuania isaskedtoInitiateaPreparation of theSpecialLawDedicatedfortheCuronianSpit.Availableat:https:// vkpk.lt/en/naujienos/the-parliament-of-the-republic-of-lithuania-is-asked-to-initiate-apreparation-of-the-special-law-dedicated-for-the-curonian-spit/ (accessed 21, April, 2020).

43. Nõmm, K. \& Randma-Liiv, T. (2012). Performance Measurement and Performance Information in New Democracies: A Study of the Estonian Central Government. Public Management Review, vol. 14, no 7, pp. 859-879.

44. Pociūte, G. (2012). The Problem of Klaipedda Region Peripherality. Regional Formation and Developement Studies, vol. 1, no 6, pp. 93-103.

45. Poister, T.H., Pasha, O.Q. \& Edwards, L.H. (2013). Does Performance Management Lead to Better Outcomes? Evidence from the US Public Transit Industry. Public Administration Review, vol. 73, no 4, pp. 625-636.

46. Pasha, O. (2018). Can Performance Management Best Practices Help Reduce Crime? Public Administration Review, vol. 78, no 2, pp. 217-227.

47. Rauleckas, R., Nakrošis, V., Šnapštienè, R. \& Šarkutè, L. (2016). The Impact of Public Administration Reforms in Lithuania: Systemic Managerial Changes and Persisting Organizational Differences. Public Administration Reforms in Europe: The View from the Top, Cheltenham: Edward Elgar Publishing Limited, pp.105-116.

48. Schleicher, D.J., Baumann, H.M., Sullivan, D.W., Levy, P.E., Hargrove, D.C. \& Barros-Rivera, B.A. (2018). Putting the System into Performance Management Systems: A Review and Agenda for Performance Management Research. Journal of Management, vol. 44, no 6, pp. 2209-2245. 
49. Shields, B. P., Moore, S. A. \& Eagles, P. F. (2016). Indicators for Assessing Good Governance of Protected Areas: Insights from Park Managers in Western Australia. Parks, vol. 22, no 1, pp. 37-50.

50. Sorin, D.A.N. (2015). The New Public Management is Not That Bad After All: Evidence from Estonia, Hungary and Romania. Transylvanian Review of Administrative Sciences, vol. 11, no 44 , pp. 57-73.

51. Spano, A. (2009). Public Value Creation and Management Control Systems. Intl Journal of Public Administration, vol. 32, no 3-4, pp. 328-348.

52. Stufflebeam, D.L. \& Shinkfield, A.J. (2007). Evaluation Theory, Models and Applications. SanFrancisco: Jossey-Bass.

53. Sun, R. \& Van Ryzin, G.G. (2014). Are Performance Management Practices Associated with Better Outcomes? Empirical Evidence from New York Public Schools. The American Review of Public Administration, vol. 44, no 3, pp. 324-338.

54. Vedung, E. (2007). Policy Instruments: Typologies and Theories. In: M.L. Bemelmans-Videc, R.C. Rist, E. Vedung (eds.). Carrots, Sticks \& Sermons. New Brunswick, London: Transaction Publishers.

55. Verbeeten, F. H. (2008). Performance Management Practices in Public Sector Organizations: Impact on Performance. Accounting, Auditing \& Accountability Journal, vol. 21, no 3, pp. 427-454.

56. Van Der Meer, F. B. (1999). Evaluation and the Social Construction of Impacts. Evaluation, vol. 5, no 4, pp. 387-406.

57. Van Dooren, W., Bouckaert, G. \& Halligan, J. (2010). Performance Management in the Public Sector. Routledge.

58. Verheijen, T. \& Dobrolyubova, Y. (2007). Performance Management in the Baltic States and Russia: Success against the Odds? International Review of Administrative Sciences, vol. 73, no 2, pp. 205-215.

59. Veselý, A. (2013). Accountability in Central and Eastern Europe: Concept and Reality. International Review of Administrative Sciences, vol. 79, no 2, pp. 310-330.

60. Watson, J., Allan, J., Jones, K. et al. (2018). One Third of the World's Nature Reserves are Under Threat Humans. The Conversation. Available at: http://theconversation.com/one-third-of-theworlds-nature-reserves-are-under-threat-from-humans-96721; https://www.tandfonline.com/ doi/pdf/10.1080/15309576.2019.1702064?needAccess=true (accessed: 27 January, 2020).

61. Weiss, J. (2019). Managing Performance and Strategy: Managerial Practices in German Local Governments. Public Performance \& Management Review, pp. 1-21.

62. World Bank (2019). Terrestrial Protected Areas (\% of Total Land Area). Available at: https:// data.worldbank.org/indicator/ER.LND.PTLD.ZS (accessed: 27 January, 2020).

63. Yakusheva, N. (2017). Parks, Policies and People. Nature of Conservation Governance in PostSocialist EU Countries. Ph.D. Thesis, Södertörn University.

64. United Nations (2019). World Heritage List. Available at: https://whc.unesco.org/en/list/994/ (accessed: 02 February, 2020).

65. Zope, R., Vasudevan, N., Arkatkar, S.S. \& Joshi, G. (2019). Benchmarking: A Tool for Evaluation and Monitoring Sustainability of Urban Transport System in Metropolitan Cities of India. Sustainable Cities and Society, no 45, pp. 48-58. 